\title{
Conductor of the Astrocyte-Neuron Metabolic Orchestra
}

\author{
Menizibeya O. WELCOME ${ }^{*_{0}}$
}

\section{Conductor of the Astrocyte-Neuron Metabolic Orchestra}

\section{SUMMARY}

Disorders such as diabetes mellitus, obesity, Parkinson's, and Alzheimer's diseases are characterized by central metabolic dysfunctions and pose an enormous economic burden to public health. Annually, several millions of new cases and deaths are reported worldwide, thus substantiating the need to search for new frontiers in combating the growing prevalence and mortality of these diseases. Over the past few years, scientific evidence has consistently shown that the functional sweet taste receptor, $T 1 R 2+T 1 R 3$ heterodimer, serves to direct (conduct) peripheral glucose metabolism. Recent data have revealed that this heterodimer can also act as a central glucosensor that conducts cerebral glucose metabolism. Emerging reports have confirmed the central role of this receptor as a driver of glucose metabolism in neurons and astrocytes. In this paper, "metabolic orchestra" is used to depict the organizational complexity of the plasma membrane receptor-network involved in coordinating glucose transport and metabolism in the astrocyte-neuron circuitry. In light of recent works, suggesting that the taste receptor is a crucial central glucosensor and master coordinator of glucose metabolism, here, the $T 1 R 2+T 1 R 3$ heterodimer is referred to as the metabolic conductor of the astrocyte-neuron circuitry, responsible for a highly coordinated signaling of glucose molecules and multi-directional cross-talk with other plasma membrane receptors. This concept represents a shift on the astrocyte-neuron metabolic machinery from the GLUT2 mediated entry of glucose to a more coordinated one, involving multiple players at the plasma membrane. Research focusing on the treatments of brain disorders involving glucose metabolic dysfunctions is also discussed.

Key Words: T1R2+T1R3; cerebral sweet taste receptor antagonists; glucosensors; metabolic conductor; metabolic orchestra; cerebral diseases

\section{Astrosit-Nöron Metabolik Orkestrasının Şefi}

$\ddot{O} Z$

Diabetes mellitus, obezite, Parkinson ve Alzheimer hastaliklar gibi bozukluklar, merkezi metabolik işlev bozukluklar ile karakterize edilir ve halk sağlığrna çok büyük ekonomik yük oluşturur. Dünya çapında her yil milyonlarca yeni vaka ve ölüm rapor edilmektedir, bu durum bu hastalıklarn artan yayginliğ ve ölüm oranıyla mücadele etmek için yeni çözümler arayışını ortaya koymaktadir. Son birkaç yuldir bilimsel kanitlar, tatl tat almaya yardimcı reseptör $T 1 R 2+T 1 R 3$ heterodimerinin periferal glukoz metabolizmasın yönlendirmeye hizmet ettiğini tutarlı bir sekilde göstermiştir. Son veriler, bu heterodimerin ayn zamanda serebral glukoz metabolizmasinı gerçekleștiren merkezi bir glukosensör görevi gördüğünü ortaya çıkarmıştır. Elde edilen bulgular, bu reseptörün nöronlarda ve astrositlerde glukoz metabolizmasinin itici gücü olarak merkezi rolünü doğrulamaktadır. Bu makalede, "metabolik orkestra", astrosit-nöron devrelerinde glukoz taşınmasinı ve metabolizmasin koordine etmede yer alan plazma membran reseptör ă̆ının organizasyonel karmaşıkliğın tasvir etmek için kullanilmıștır. Bu derleme, son zamanlarda yapılan çalışmaların ış̆ğında, tat reseptörünün çok önemli bir merkezi glukosensör ve glukoz metabolizmasının ana koordinatörü olduğunu öne sürerek, astrosit-nöron devresinin metabolik iletkeni olarak T1R2+T1R3 heterodimerine atıfta bulunmaktadir; buna göre glukozun hücre içine GLUT-2 aracıl girişinden ziyade plazma zarnda astrositnöron metabolik mekanizmasın içeren daha koordineli bir giris açıklanmaktadır. Ayrıca, glukoz metabolik disfonksiyonların içeren beyin bozukluklar için yeni tedavi yollar sağlayabilecek araştırma konular da tartışılmıştır.

Anahtar kelimeler: $T 1 R 2+T 1 R 3$; serebral tatlı tat reseptörü antagonistleri; glukosensörler; metabolik iletken; metabolik orkestra; beyin hastaliklar

Received: 05.03.2021

Revised: 14.06 .2021

Accepted: 10.09.2021

• ORCID: 0000-0001-5737-4626, Department of Physiology, Faculty of Basic Medical Sciences, College of Health Sciences, Nile University of Nigeria, Abuja 


\section{INTRODUCTION}

Recent reports strongly indicate that disorders such as diabetes mellitus, obesity, Parkinson's, and Alzheimer's diseases are characterized by dysfunction in central metabolism machinery (Cai, 2012; Khatri, 2013). Though these diseases are complex and multifactorial (Procaccini, 2016; Guo, 2013), metabolic dysfunction is critical to their development, progression, or complications (Kaidanovich-Beilin, 2012; Vercruysse, 2018). Over the past four decades, statistics have shown a constant increase in the prevalence of these central metabolic disorders as several millions of new cases are reported annually. Furthermore, these disorders represent a significant cause of death and disability in the world (Chin, 2014; Wittchen, 2010). They contribute primarily to neurological diseases and are associated with an enormous financial burden (Gustavsson, 2011). Obesity and diabetes are independent risks for cardiovascular diseases and cancer, with their repercussions constituting a major global concern (Abdelaa, 2017; van Dieren, 2010). If the trends continue, $20 \%$ of the entire world population will suffer from obesity by 2030 (Arroyo-Johnson \& Mincey, 2016). Similarly, the world population of diabetes mellitus will increase to 380 million by 2025 (van Dieren, 2010) or 592 million by 2035 (Forouhi, 2014).

Accordingly, the problems posed by these diseases to public health, sufferers, caregivers, and their families cannot be overemphasized (Lozano, 2012), thus, substantiating the need to search for alternative strategies to combat the growing prevalence and mortality of these diseases.

Over the past decade, evidence suggests that the functional sweet taste receptor, T1R2+T1R3 heterodimer, acts to direct peripheral glucose metabolism (Depoortere, 2014). New data have shown that this taste heterodimer also directs cerebral glucose metabolism (Murovets, 2014, 2015), and recently, reports have confirmed the central role of this receptor as a driver and coordinator of glucose metabolism in both neurons and astrocytes (Benford, 2017; Kohno, 2017). The functional taste receptors appear to interact with a wide range of membrane receptors to coordinate central metabolism (Welcome, 2015; Kochem, 2017). In this paper, "metabolic orchestra" is used to depict the organizational complexity of the plasma membrane receptor network involved in coordinating glucose transport and metabolism in the astrocyte-neuron circuitry. Pharmacological intervention directed on the T1R2+T1R3 heterodimer holds promise to address some brain diseases involving dysfunctions in central metabolic machinery.

Similar to macrocosmos, organizational activities in the cellular world tend to resemble some physical phenomena in nature. A typical example is a similarity between Mandelbrot fractals and cellular processes occurring in neurons and muscle cells (Goldberger, 1990). Another intriguing example is the orchestra, a large group of an instrumental ensemble of musicians playing a variety of different instruments (Westrup, 2001; Ford, 2003). A particular feature of the orchestral organization is a generally accepted hierarchy: every instrumental section has a principal whose responsibility is to lead the group. The principal commander in the orchestra is the conductor, who directs group masters (Lim, 2014; Dobson, 2013). This organizational pattern and actions at the orchestra may be compared with activities occurring in the metabolic arena.

The "metabolic orchestra" of the astrocyte-neuron circuitry comprises a plethora of signaling molecules that interact to constantly evaluate, regulate and synthesize energy and other molecules in accordance with the physiological needs of the organism. Hormones, neurotransmitters, and other molecules, including the metabolic substances themselves (Welcome, 2015), control this metabolic process. Thus, the "metabolic orchestra" of the astrocyte-neuron circuitry is critical for the brain to process all types of information, including cognitive processes. Specific receptors appear to play a pivotal role in metabolic processes; In the central nervous system, for instance, specific plasma membrane receptors regulate the influx of metabolites to maintain an adequate level of energy substrates needed for cellular processes (Wel- 
come, 2015; Welcome, 2018). Glucose is the most important energy substrate for cerebral functioning (Welcome, 2014). The utilization of glucose by the brain has traditionally been explained with models or theories. The generally accepted models of cerebral glucose metabolism are the astrocyte-neuron lactate shuttle (ANLS) (Pellerin, 1994) and the glucosensor (Burdakov, 2005) hypotheses. The ANLS hypothesis posits that metabolic coupling between neurons and astrocytes is maintained by astrocyte-generated lactate, which is transported out through astrocyte types 1 and 4 monocarboxylate transporters (MCT1 and MCT4) into neurons through MCT2. This process is closely regulated by the glutamate-glutamine cycle. Lactate molecules in neurons are further metabolized in the Krebs, or tricarboxylic acid (TCA) cycle to produce energy (ATP) and other biomolecules to maintain neuronal activity (Kasischke, 2009; Hubbard \& Binder 2016). The ANLS was the most accepted hypothesis of cerebral glucose metabolism until recently, independent groups of researchers across the globe have revealed a critical role of the glucosensor model in explaining the mechanisms of cerebral glucose regulation in health and disease (Welcome, 2015; Murovets, 2015; Benford, 2017). This conceptual shift was mainly due to the shortcomings of the ANLS hypothesis (Dienel, 2017a). Though the ANLS has been modified over the years to account for recent development in brain metabolism (Pellerin, 2007; Genc, 2011), there is a need for further revision or investigation that can ultimately lead to the discovery of an all-encompassing model of cerebral glucose metabolism to account for recent findings in the literature.

The latest evidence suggests that sweet taste receptors functioning as neuronal and astrocyte glucosensors play a considerable role in controlling glucose metabolism in the brain (Benford, 2017; Kohno, 2017). Indeed preliminary results of studies conducted in animals have shown that impairment in sweet taste receptor signaling is associated with glucose metabolic disorder (Murovets, 2014, 2015). Sweet taste receptors can be defined as transmembrane proteins involved in the sensing, coding, and relay of information from "sweet" molecules downstream several acceptors to modulate cell metabolism and activity. These taste receptors are classified as group 1 taste receptors, having three subtypes - T1R1, T1R2, and T1R3 (Welcome, 2015). However, functional sweet taste receptor occurs as T1R2+T1R3 heterodimer (vide supra). This functional receptor is activated by an abundance of ligands, which include monosaccharides (e.g., glucose, fructose), disaccharides (e.g., maltose, lactose, and sucrose), amino acids (e.g., alanine, glycine, D-histidine, D-tryptophan), sweet proteins (e.g., neoculin, monellin, thaumatin, neotame, aspartame), among others (Welcome, 2015; Ahmad, 2020). In contrast, type 2 taste receptors recognize bitter or potentially poisonous substances such as alkaloids, acids, and toxins (Meyerhof, 2010; Lu, 2017).

In light of accumulating pieces of evidences suggesting that sweet taste receptors are the master coordinator of glucose metabolism in the brain (Ren, 2009; Murovets, 2014, 2015; Welcome, 2015; Kohno, 2016; Kohno, 2017), and experimental data showing a crucial role of these receptors in glucosensing (Ren, 2009; Benford, 2017; Martin, 2017), the T1R2+T1R3 heterodimer is referred to as a metabolic conductor of the astrocyte-neuron circuitry, responsible for cross-talks with other plasma membrane receptors in the "metabolic orchestra". This concept represents a critical shift in views on the astrocyte-neuron metabolic machinery from the GLUT-2 mediated entry of glucose to a more coordinated entry involving multiple players at the plasma membrane. This review also discusses potential research directions that may yield new therapeutic modalities for brain disorders involving metabolic dysregulation such as diabetes mellitus, obesity, and Alzheimer's disease.

\section{Cerebral Glucose Metabolism}

Brain functions depend predominately on the influx, transport, and metabolism of glucose by astrocytes and neurons (Welcome, 2015; Welcome, 2014). Despite its small mass (i.e., only $2 \%$ of the total body mass), the brain dissipates roughly $75 \%$ (i.e., $120 \mathrm{~g}$ ) of the daily needs of the body under normal resting 
state. This high rate of cerebral metabolic needs is primarily determined by the rate of cerebral information processing, controlled by neuro-hormones and transmitters (Supplie, 2017; Foo, 2012). Nevertheless, the capacity of the brain for the storage of energy substrates is abysmally low. Under normal circumstances, glucose is readily delivered to the brain. However, during fasting, the brain maintains a high demand for glucose; peripheral tissues switch to use non-carbohydrate sources for fuel. Furthermore, the brain can also use ketone bodies for energy during prolonged fasting. This property of the brain is required to ensure adequate maintenance of neuronal activity (Peters 2004; Attwell, 2004). In the following sections, the models of cerebral glucose metabolism essential to this review will be discussed; compelling evidence about the overwhelming role of T1R2+T1R 3 as the conductor of astrocyte-neuron metabolic circuit will also be provided.

\section{ANLS model of cerebral glucose metabolism}

Pellerin \& Magistretti (1994) are pioneers that developed the initial concept about the ANLS hypothesis. The major tenets of this model posit that neuronal metabolism is dependent primarily on astrocyte-generated lactate via glycolysis following stimulation by synaptically secreted glutamate (Figure 1). Some glutamate molecules activate the postsynaptic neuron, while the remaining diffuse into the astroglia through excitatory amino acid transporter-1, also known as sodium-dependent glutamate aspartate transporter-1 (GLAST-1) with a corresponding influx of sodium ions. This change in the stoichiometry of cytosolic ions activates the astrocyte $\mathrm{Na}^{+} / \mathrm{K}^{+}$ATPase, which mediates a resultant shift in potential of the astrocyte membrane (Kasischke, 2009). The release of neuronal glutamate and activity of the astrocyte $\mathrm{Na}^{+} / \mathrm{K}^{+}$ATPase is dependent on neuronal activity (Burdakov, 2005) and define the degree of metabolic activity in astrocytes leading to the production of ATP, lactate, and other molecules that maintain information processing in astrocytes and neurons (Pellerin, 1994; Burdakov, 2005; Kasischke, 2009; Hubbard, 2016).

Lactate produced by astrocytes is moved into neu- rons and incorporated into the TCA cycle for further metabolic reactions that ultimately release more fuel, transmitters, and other substances to maintain neuronal activities (Figure 1) (Kasischke, 2009; Hubbard, 2016). Though lactate is believed to be primarily produced in astrocytes (Magistretti, 2018), it can be transported from the circulation into these stellate-shaped glia, from where it may be released into the extracellular space (Kasischke, 2009) via gap junction connexins and diffuses to neighboring cells (Hertz, 2014). Thus, these glial cells form a vital nexus that couple cerebral endothelial glucose uptake to neuronal metabolism that ensures a continuous functioning of the brain (Kasischke, 2009; Hubbard, 2016). Neuronal expression of lactate dehydrogenase isoforms supports the ANLS hypothesis (Pellerin, 1994).

Glutamate-glutamine cycling is critical in cerebral glucose metabolism

Disorders in glutamate-glutamine cycling have been implicated in several central nervous system diseases that also display astrocyte-neuron metabolic impairment (Behrens, 2002; Bak, 2011). Interestingly, glutamate is a principal excitatory neurotransmitter in the central nervous system and is also produced in the Krebs cycle and recycled between astrocytes and neurons (Petroff, 2007). Upon release of glutamate by neurons, it is readily transported into astrocytes and converted to glutamine by ferredoxin-dependent glutamine oxoglutarate aminotransferase-1, also known as glutamine synthase- 1 . The conversion product of the reaction is also readily released through the sodium-coupled neutral amino acid transporter, SNAT3, depending on the concentration of astrocyte glutamate. SNAT1 and SNAT2 move the released glutamine into neurons from the extracellular space. SNATs readily cotransport one molecule of glutamine together with one sodium ion while moving one proton in the reverse direction (Bhutia \& Ganapathy, 2016; Rubio-Aliaga \& Wagner, 2016). Once in the cytosol of neuronal cells, glutamine undergoes a chemical reaction mediated by glutaminase to produce ammonia and glutamate (Petroff, 2007). 


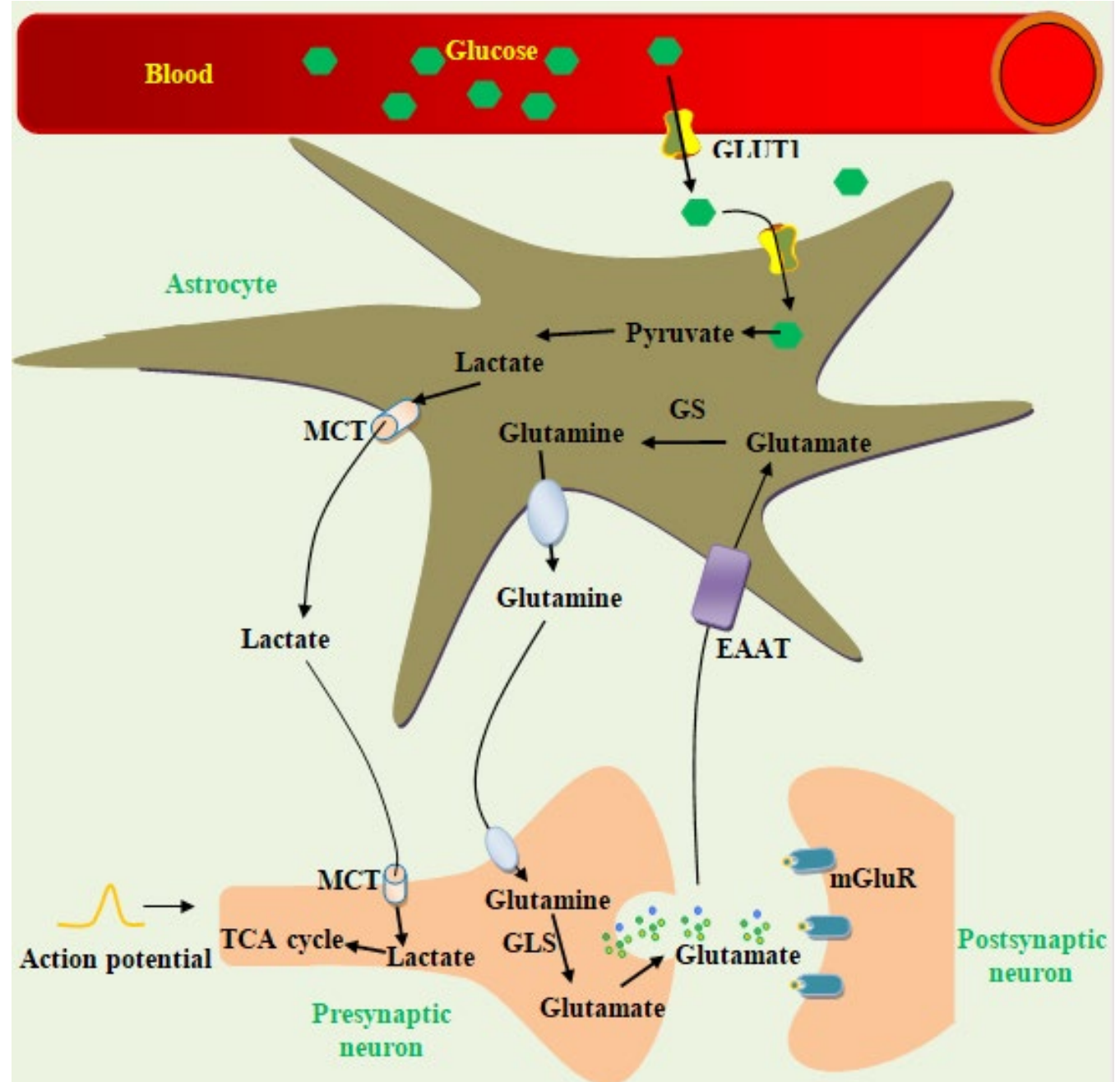

Figure 1. Schematic representation of the main tenets of the ANLS (astrocyte-neuron lactate shuttle) hypothesis. The influx of glucose into the brain from the circulation occurs via the glucose transporter (GLUT1) and is metabolized via glycolysis. Metabolism of one molecule of glucose in the cytosol produces four molecules of ATP and two molecules of NADH and two molecules of lactate. However, this metabolic pathway uses up two molecules of ATP and one molecule of NADH (Pellerin \& Magistretti, 1994; Burdakov, 2005). Lactate is exported out of the cell via the monocarboxylate transporters (MCTs; they function as proton-coupled transporters of lactate, ketone bodies, and pyruvate). The astrocyte-derived lactate is exported via MCT4 and MCT1, diffuses into neurons via MCT2 (MCT1 is also expressed in endothelial and other glial cells) (Kasischke, 2009; Hubbard \& Binder, 2016). Neuronal activity initiates glutamate release by neurons. This excitatory neurotransmitter diffuses to the postsynaptic neuron, activating the postsynaptic mGluR (metabotropic glutamate receptors), and also, into astrocytes via the EAAT (excitatory amino acid transporter). Glutamate in the astrocyte is converted by glutamine synthetase (GS) to glutamine. Finally, glutamine is transported into neuronal cells, and subsequently converted by glutaminase (GLS) to glutamate. 
However, imported glucose into astrocyte from the blood-brain barrier through GLUT1 facilitated diffusion (Figure 1) may be stored as glycogen, a temporary energy depot that is depleted instantly upon stimulation of cerebral activity (Kasischke, 2009; Hubbard, 2016; Rao, 2006). Indeed, scientific experiment has demonstrated appreciable expression of the enzymes, glycogen synthase and glycogen phosphorylase, in astrocytes, suggesting an indispensable role of these glial cells in cerebral gluconeogenesis (Wiesinger, 1997).

Nonetheless, glutamate decarboxylase can mediate the conversion of neuronal glutamate to gamma-aminobutyric acid (GABA). But glutamate may be released into the synaptic cleft upon glutamatergic stimulation (Petroff, 2007). Importantly, data indicate that glutamatergic stimulation of astrocyte metabolism is associated with increased lactate production via the action of lactate dehydrogenase on pyruvate, generated from glucose metabolism (Magistretti \& Allaman, 2018).

\section{Shortcomings of the ANLS hypothesis}

Though the ANLS model essentially improved our knowledge of cerebral glucose metabolic functions, it failed to account for new experimental data that showed non-reliance of neurons on astrocyte-derived lactate (Dienel, 2017a; Lundgaard, 2015; Patel, 2014). Accumulating data indicate that neurons display relatively high uptake (from the blood-brain barrier) and glucose metabolism in both resting and stimulated states (Patel, 2014; Bartlett, 1987; DíazGarcía \& Yellen, 2019). In the stimulated state, however, an increase in cerebral function is dependent on the increase in cerebral blood flow (Díaz-García \& Yellen, 2019). Interestingly, Patel (2014) established that not astrocyte-generated lactate is responsible for powering neuronal energy needs, but pyruvate derived from neuronal glucose metabolism. Indeed, proponents of the ANLS model in a relatively recent publication argued that the hypothesis does not exclude direct neuronal uptake of glucose (Magistretti \& Allaman, 2018). Direct neuronal uptake of glucose has also been demonstrated by Kong et al. (2017) and further discussed by Díaz-García \& Yellen (2019) and DiNuzzo (2010), who opined that the differences in carbon-substrate utilization by astrocytes and neurons might be explained at the level of glucose uptake by different brain cells, not necessarily lactate shuttle. Contrary to the preferential astrocyte uptake of glucose postulated in the original hypothesis (Pellerin \& Magistretti, 1994), Lundgaard et al. (2015) demonstrated in awake-active experimental rodents that preferential transport of glucose occurs in neurons, not astrocytes as previously reported. Notably, the glycolytic enzyme, hexokinase, which is involved in the catalysis of the first step of glucose metabolism, is richly expressed in neurons than in astrocytes, suggesting that neurons may not even need astrocyte-generated lactate to power their energy requirements (Lundgaard, 2015). This, indeed, indicates that neurons may even exhibit a higher rate of glycolysis than the stellate-shaped glial cells (Lundgaard, 2015).

In conflict with one of the central tenets of the ANLS model, assuming that lactate derived from astrocytes is the primary substrate that feeds neurons (Pellerin \& Magistretti, 1994; Magistretti \& Allaman, 2018), independent groups of researchers have shown that neurons can produce their lactate from glucose and that astrocyte-generated lactate is not a prerequisite for neuronal metabolic processes. So, Dienel (2017b) showed that shuttling of lactate from astroglial cells to neurons does not make a substantial contribution to neuronal energetics.

It was thought that gluconeogenesis exclusively occurs in astrocytes due to their expression of glycogen synthase and glycogen phosphorylase; nonetheless, evidence has shown that neurons also express these enzymes, which are required for the metabolism of glycogen (Saez, 2014; Pfeiffer-Guglielmi, 2014). Though the neuronal forms of the glycogen metabolic enzymes may not be very active under physiological conditions, they remain essential in hypoxia and other abnormal conditions, including neurodegenerative disorders (Pfeiffer-Guglielmi, 2014; Duran, 2012). 
Inconsistent with previous belief that cleavage of astrocyte glycogen produces lactate, Dienel and Cruz (2004) demonstrated that stimulation of cerebral activity leads to utilization of glycogen cleavage products by astrocytes themselves, not neurons, thereby challenging the ANLS hypothesis (Pellerin, 1994; Magistretti, 2018). To resolve this controversy, Mangia et al. (2009), using functional magnetic resonance spectroscopy, revealed the existence of both ANLS and neuron-to-astrocyte lactate shuttle (NALS). Surprisingly, however, it was shown that ANLS was only possible if the transport capacity of astrocyte glucose increased by 12 times in the presence of neuronal non-responsiveness to stimulation with a raised glycolytic activity (Mangia, 2009). The latter process is unlikely, suggesting that only one process may favorably occur. There is, therefore, need to address these inconsistencies in data reported by different authors. Indeed, Supplie et al. (2017) reported that astrocytes and neurons exchange energy-rich metabolites.

Interestingly, whether astrocyte- or neuron-derived, lactate has been shown to play a critical role in memory formation. For instance, experimental data have demonstrated that deletion of the astrocyte MCT1 and MCT4 or neuronal MCT2 leads to amnesia. This indicates that lactate import into neurons is essential for neuronal functions, and in particular long-term memory formation. Suzuki et al. (2011) suggested that astrocyte glycogenolysis is crucial for induction of molecular signaling cascades associated with memory consolidation through activation of CREB (cAMP response element-binding protein), Arc, and cofilin. Likewise, Newman et al. (2011) showed that lactate in the brain is important for memory consolidation. Similar data are reported elsewhere (Kong, 2017). More recently, neuronal lactate has been implicated in the induction of neurogenesis (Lev-Vachnish, 2019).

Hall and coworkers (2012) also reported data opposing the ANLS model. The authors showed that oxidative phosphorylation, not shuttling of astrocyte-generated lactate, constitutes the principal mechanism that feeds neurons with energy molecules. As previously noted in the ANLS model, $\mathrm{Na}^{+} / \mathrm{K}^{+}$ATPase consumes a substantial proportion of the energy produced by biochemical reactions in the brain (Pellerin \& Magistretti, 1994; Kasischke, 2009). This finding has been confirmed by several authors, including Foo et al. (2012), who further noted that ATP utilization by neurons in addition to the $\mathrm{Na}^{+} / \mathrm{K}^{+}$ATPase activity depends on NMDA (N-methyl-D-aspartate) receptor activity, and not necessarily on neuronal activity. These views have been confirmed in cerebral pathology such as cerebral stroke, in which depletion of neuronal energy molecules is associated with excessive secretion of glutamate. This transmitter activates the NMDA receptor (Foo, 2012).

Undoubtedly, glutamate activates glucose transport in astrocytes. But the transmitter also inhibits glucose transport in neurons through AMPA ( $\alpha$-amino-3-hydroxy-5-methyl-4-isoxazole propionic acid) receptor-mediated sodium entry. Thus, upon stimulation of glutamatergic synapses, neuronal cells should have decreased glucose availability, while astrocytes should have increased the quantity of glucose (Porras, 2004). Nevertheless, data regarding astrocyte-neuron glucose metabolism suggest that this is usually not the case (Hall, 2012; Dienel, 2017b; Lundgaard, 2015).

Again, the ANLS model did not consider lactate transport through the blood-brain barrier to brain cells via MCT1. To this end, data have revealed that a rise in brain lactate level can stimulate astrocyte glycolytic and glycogenolytic pathways, suggesting that lactate is actively taken up by astrocytes for energy metabolism (Petroff, 2007). In addition, the ANLS model is energetically unfavorable for astrocytes in the long term. However, since astrocytes are relatively resilient to hypoxia, they tend to maintain neuronal survival during condition of inadequate oxygen and glucose supply (Genc, 2011). These data strongly contradict the ANLS; thus a redefinition of the model is crucial.

Glucosensor model of cerebral glucose metabolism

Identification of neurons and astrocytes that act as glucosensors was demonstrated in the 1980s (Kow, 
1985; Mizuno, 1984). Glucosensors can be categorized as the plasma membrane and intracellular glucosensors. Over the past decades, several researchers have revealed an essential role of multiple players in regulating the astrocyte-neuron glucose metabolic circuitry (Kyriazis, 2012; Welcome, 2015). These central glucosensors are discussed below.

\section{Plasma membrane glucosensors of the brain}

Plasma membrane glucosensors are those glucosensors expressed on the membrane of neurons, astrocytes (Burdakov, 2005), and the choroid plexus epithelial and ependymal cells (Chiba, 2020; Duarte, 2020). The expression of plasma membrane glucosensors confers these cells the ability to integrate multiple signals from different sources (Roh, 2016; Marty, 2007). The neuronal glucosensors of the plasma membrane are GLUT2 (Shah, 2012; Koekkoek, 2017), sodium-glucose cotransporter (SGLT) type 3, and Kir6.2 subunit of the ATP-dependent potassium (K-ATP) channel (Kang, 2004). Astrocytes express glucosensors GLUT2 and Kir6.1 subunit of the K-ATP channel (Shah, 2012; García, 2003). Finally, the choroid plexus epithelial and ependymal cells express GLUT2 (Chiba, 2020). The latest member of the plasma membrane glucosensors, sweet taste receptor heterodimer, is expressed in neurons, astrocytes, and choroid plexus epithelial cells (Duarte, 2020). This review is mainly concerned with neuronal and astrocyte taste receptors due to the frequent involvement of these cells in brain pathologies. The glucosensors have been implicated in a couple of diseases involving cerebral metabolic impairment. Interestingly, defects in plasma membrane glucosensors of the brainstem and hypothalamus, primarily the sweet taste receptors and GLUT2, are believed to play an integral role in the pathogenesis of Alzheimer's disease, diabetes mellitus, and obesity, among others (Dienel \& Cruz, 2004; Shah, 2012). Bady and colleagues also reported impaired feeding behavior in laboratory animals with GLUT2 deficiency (Bady, 2006), suggesting that this membrane glucosensor may drive behavioral disorders associated with obesity, bulimia nervosa, anorexia, and even schizophrenia (Jouroukhin, 2018). Whether or not cerebral glucose metabolic impairment constitutes an underlying mechanism involved in the development of neurodegenerative diseases remains a contemporary subject of discussion (Kamat, 2016; De la Monte, 2018).

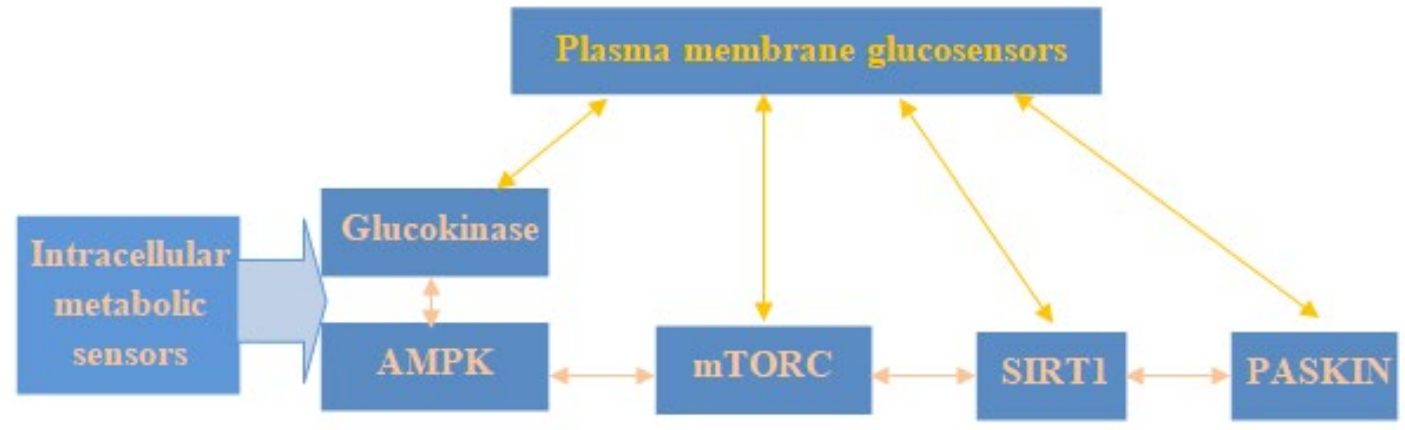

Figure 2. Interaction between intracellular metabolic sensors and membrane glucosensors (see explanation in text).

\section{Intracellular glucosensors}

Pieces of evidence strongly indicate that molecules such as sirtuins, mTOR (Mechanistic or Mammalian Target of Rapamycin), AMPK (AMP activated protein kinase), Per-Arnt-Sim kinase (PASKIN, PSK or PASK), and glucokinase (hexokinase IV) function as intracellular metabolic (glucose) sensors in neurons and astrocytes. To effectively regulate the glucose metabolism in the brain, these intracellular glucosensors interact amongst themselves and also with the membrane glucosensors (Figure 2) (Shah, 2012; Koekkoek, 2017; García, 2003). 


\section{Glucosensors can mediate glucose transport and} metabolism through circulating neurotransmitter levels

Glucose transport and metabolism are mediated by the glucosensor-neurons of the hypothalamus and brainstem (Koekkoek, 2017; Burdakov, 2005), nucleus accumbens, and amygdala (Burdakov, 2005). The glucose-inhibited cells sense a reduction in extracellular glucose level via a decrease in cytosolic $\mathrm{Ca}^{2+}$ oscillations as glucose level increases from 0.1 to 5 mmol/L (Kang, 2004; García, 2003). However, some glucose-inhibited neurons can sense a higher glucose concentration - above $5 \mathrm{mmol} / \mathrm{L}$ (García, 2003). The glucose-excited neurons increase intracellular $\mathrm{Ca}^{2+}$ oscillations as glucose level rises from 0.5 to 2.5 $\mathrm{mmol} / \mathrm{L}$. These neurons can respond to extracellular levels of not only metabolic substrates (glucose, lactate, ketone bodies) but also insulin, leptin, and other neurotransmitters (Koekkoek, 2017).

The glucosensor-neurons are called neuropeptide Y (NPY)/Agouti-related protein (AgRP) or proopiomelanocortin (POMC) neurons, depending on the most abundant neurotransmitter. These neurons, which are either glucose-inhibited or glucose-excited, also express the intracellular and plasma membrane glucosensors, and regulate energy expenditure as well as feeding behavior (Fioramonti, 2007; De Morentin, 2011). The POMC glucosensing neurons are known to dampen appetite, and thus, are anorexigenic or glucose excited. The NPY/AgRP neurons, on the other hand, promote appetite, and therefore, are called orexigenic or glucose inhibited (Burdakov, 2005; Essner, 2017). AgRP/NPY and POMC neurons of the hypothalamic arcuate nucleus, the primary energy-sensing brain region, comprise the melanocortin system. This system is essential for maintaining energy balance and feeding behavior (Belgardt, 2009). POMC neurons also produce $\alpha$-melantropin, also known as $\alpha$-melanocyte-stimulating hormone ( $\alpha-\mathrm{MSH})$. The glucosensors of the POMC neurons detect an increase in extracellular glucose, which subsequently leads to an increase in membrane depolarization. This change in membrane potential may translate to the release of neurotransmitters or neuropeptides. Correspondingly, $\alpha-\mathrm{MSH}$ is secreted in POMC neurons in response to membrane depolarization. The released $a-\mathrm{MSH}$ stimulates melanocortin-4 receptors (MCR4) located on the membrane of neighboring neurons to mediate a couple of physiological processes. MCR4 activation by $\alpha-\mathrm{MSH}$ can culminate in reduced food ingestion and increased energy expenditure (Belgardt, 2009). The NPY/AgRP neurons inhibit the stimulation of MC4R by a-melantropin (Belgardt, 2009).

Multiple lines of evidence indicate a critical role of AMPK, mTOR, sirtuins, PASK, and glucokinase in intracellular glucosensing (Shah, 2012; Koekkoek, 2017; García, 2003). However, the precise molecular mechanisms of glucosensing by these intracellular molecular sensors are not precisely understood. Though, specific subunits may be responsive (i.e., activated) or inhibited by certain levels of intracellular glucose, the precise molecular machinery of the neuronal and astrocyte cytosol that controls glucose metabolic activity of the cell with regards to AMPK, mTOR, sirtuins, PASK, and glucokinase are yet to be well defined. It is, therefore, necessary to investigate mechanisms of glucose-induced activation and inhibition of the intracellular glucosensors.

T1R2+T1R3 receptor as an integral sensor and regulator of cerebral glucose metabolism

Ren et al. (2009) are credited for discovering sweet taste receptors (including the functional receptor T1R2+T1R3 heterodimer) as sensors of glucose level in the hypothalamus. Interestingly, the researchers found functional sweet taste receptors and their corresponding genes in the neurons of the cortex, dentate gyrus, and CA area of the hippocampus (Ren, 2009). Notably, research data have shown considerable increase in the expression of sweet taste receptor subtypes following food deprivation, suggesting a possible compensatory mechanism required to increase glucosensing for brain activities upon reduction in energy molecules (Ren, 2009). Correspondingly, a reduction in hypothalamic level of extracellular glucose was associated with an increased expression of T1R2, which normalized following glucose adminis- 
tration (Ren, 2009). Other authors have demonstrated the presence of sweet taste receptors in hypothalamic arcuate nucleus, which is a primary brain region, concerned with energy, in particular glucose homeostasis (Kohno, 2016; Benford, 2017).

Kohno et al. (2016) later showed that sweet taste receptor responses to glucose in the hypothalamus occur in leptin-responsive neurons of the arcuate nucleus. Taste receptors of the hypothalamus are not only involved in glucose sensing but also cephalic phase responses during food ingestion. Interestingly, an animal study of T1R2+T1R3 receptors revealed that cephalic phase responses are associated with insulin release and improved glucose metabolism. While peripheral tissue taste responses were not altered in T1R2+T1R3 receptor defect, central taste responses of T1R2+T1R3 receptor showed significant alteration (Glendinning, 2015), indicating that stimulation of taste receptors of the brain can be harnessed for possible treatment of diseases involving impaired insulin secretion and signaling (Glendinning, 2015). This result also indicates strong cooperativity between T1R2+T1R3 and GLUT2 or other glucosensors (Figure 2). This association may be due to the stimulation of downstream effectors that regulate the transport activity and expression of SGLT3 or GLUT2 glucosensors. The cooperativity of T1R2+T1R3 and traditional transporters involved in glucose absorption has been reported in the gastrointestinal tract (Margolskee, 2002). Sweet taste receptor-expressing cells have been shown to selectively express different glucosensors, including Kir 6.1 subunit of the K-ATP channel, SGLT3, and GLUT2 (Yee, 2011). An increase in the number of sweeteners in meals has been associated with greater metabolic responses, indicating that stimulation of taste receptors may be an important mechanism underpinning the relationship between nutrient sensing and metabolism. To this end, beverages loaded with sweeteners have been shown to influence physiological responses that accompany carbohydrate meals (Veldhuizen, 2017). Chan, (2017) revealed that activation of sweet taste receptors by ingested non-nutritive, no-calorie sweeteners was accompanied by stimulation of glucose transport, incretin, and insulin secretion, with a resultant positive effect on glucose metabolism. Indeed, Murovets et al. (2015) previously noted that defect in T1R3 was associated with impairment of glucose clearance in mice. The authors also demonstrated the incretin effect accompanied by activation of extra-oral sweet taste receptors in the pancreas and brain. 


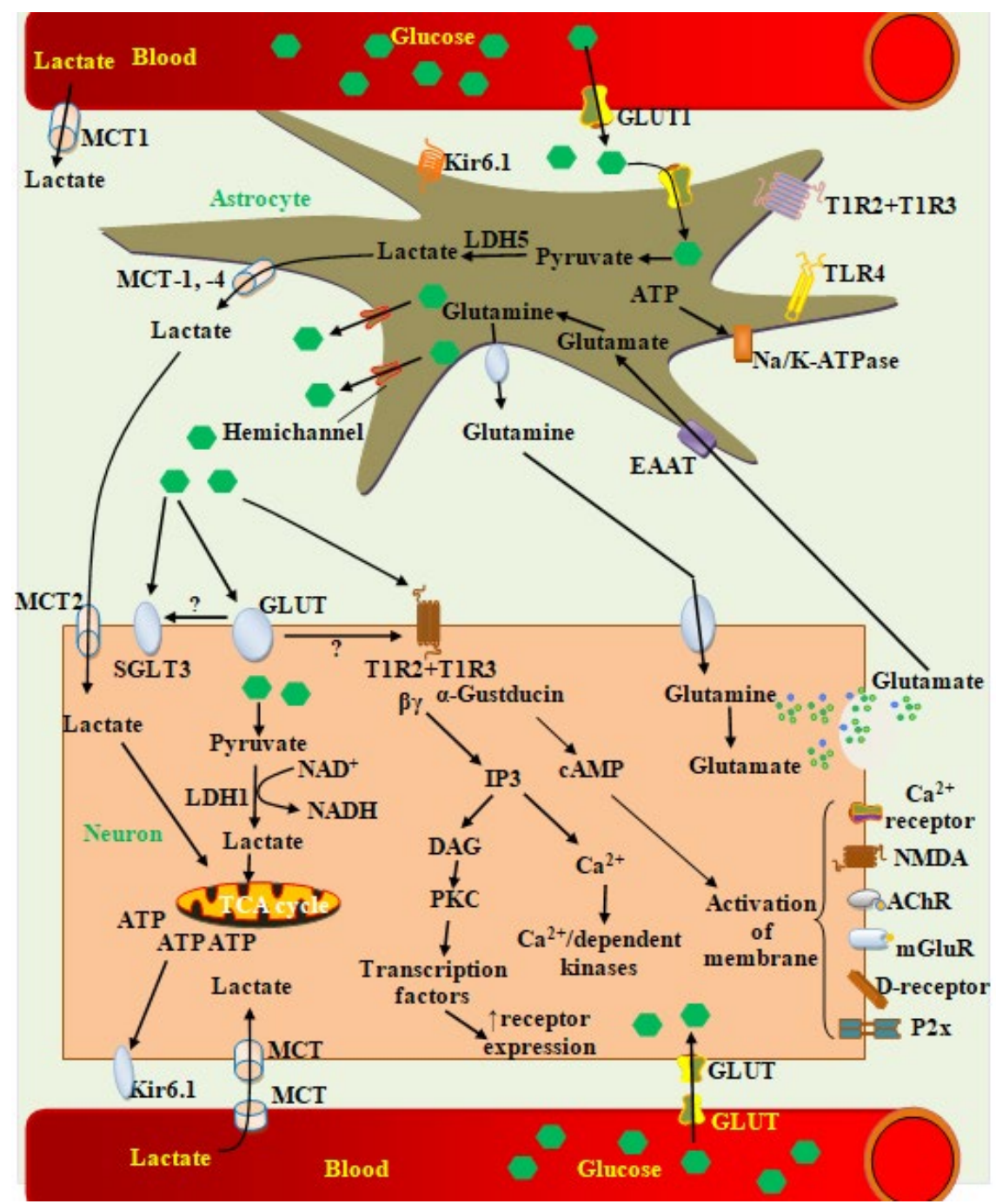

Figure 3. Schema of contemporary understanding of astrocyte-neuron metabolic coupling. The influx of glucose molecules into astrocytes and neurons occurs via the GLUcose Transporters termed GLUTs. The glucose molecules stimulate a range of membrane glucose sensors, including T1R2+T1R3, GLUT2, and SGLT3. These receptors cooperate to regulate glucose transport and metabolism. Depending on the rate of energy demand, astrocyte glucose is stored as glycogen or metabolized to generate ATP and other molecules (Welcome, 2015; Glendinning, 2015; Yee, 2011; Hamano, 2015). Products of metabolism (e.g., lactate, ATP), and glucose molecules that escape the metabolic pathways are transported through transporters, connexons, or hemichannels to the extracellular milieu (Welcome, 2015; Glendinning, 2015). Stimulation of T1R2+T1R3 by glucose in both astrocytes and neurons triggers downstream signaling mediated by the dissociated $\alpha$-subunit gustducin and $\beta \gamma$ subunits of T1R2+T1R3 following the exchange of GDP for GTP. $\alpha$-gustducin then stimulates adenylate cyclase, which produces cAMP from ATP. However, $\alpha$-gustducin can also stimulate phosphodiesterase (PDE) - an enzyme that causes a decrease in cytosolic levels of cAMP. The cAMP can activate several intracellular acceptors and membrane receptors via a cAMP-dependent pathway (Welcome, 2015). The $\beta \gamma$ subunits mediate the formation of 1,4,5-inositol trisphosphate (IP3) through activation of phospholipase C $\beta$ (PLC $\beta$ ). IP3 signals downstream activating diacylglycerol (DAG), which then stimulates protein kinase $\mathrm{C}$ (PKC) to cause substantial changes in phosphorylation of a couple of intracellular proteins. IP3 can also stimulate the IP3 receptors of the endoplasmic reticulum, which causes the release of $\mathrm{Ca}^{2+}$ into the cytosol. Elevation of cytosolic $\mathrm{Ca} 2+$ stimulates some enzymes and receptors, including calcium-dependent kinases, and monovalent selective cation channel (TRPM5) (Zhou, 2018). Elevated cytosolic $\mathrm{Ca}^{2+}$ levels can also trigger the release of ATP by P2Y1 receptors. Ca2+-dependent ATP release may be mediated by the voltage-gated ion channel, calcium homeostasis modulator 1, implicated in ATP secretion in taste-responsive cells. Numerous peptides are also secreted in the process of T1R2+T1R3 activation. T1R2+T1R3 heterodimer signaling can stimulate the transcription factors that regulate gene transcription and protein expression (Welcome, 2015; Glendinning, 2015; Yee, 2011; Hamano, 2015). 
Certain factors may affect the signaling of sweet taste receptors. For example, ageing worsens T1R3 receptor-mediated regulation of glucose homeostasis. This clearly shows that the sweet taste receptor is a candidate glucosensor, controlling extra-oral glucose metabolism, and that aging can predispose an individual to diseases related to glucose dyshomeostasis (Murovets, 2015). Indeed, accumulating reports have revealed that age-related neurodegenerative disorders, including Alzheimer's and Parkinson diseases, are linked to brain glucose metabolic disorders (Cai, 2012; Dunn, 2014; Blum-Degen, 1995). Recent research has also shown that dysfunctions in sweet taste signaling (downregulation of taste signaling components - TRPM5, a-gustducin, and PLC $\beta 2$ ) may lead to an abnormal increase in glucose level, which can, in turn, lead to elevated intracellular reactive oxygen species, decreased $\mathrm{Ca}^{2+}$ level and subsequent activation of inflammatory pathways (Zhou, 2018) (See Figure 3 for mechanisms of taste receptor signaling). The molecular networks that connect sweet taste receptor signaling to immunity may be an essential mechanism that also links sweet taste receptors with neurodegenerative and other inflammatory disorders, including diabetes mellitus (Zhou, 2018). Interestingly, accumulating reports have revealed that neurodegenerative disorders such as Alzheimer's, Parkinson and Huntington's diseases are associated with cerebral glucose metabolic dysfunction (Cai, 2012; Dunn, 2014; Blum-Degen, 1995). Thus, further research may yield potential therapeutic options for neurodegenerative diseases and diabetic complications.

Interaction of T1R2+T1R3 with other plasma membrane receptors or nodal signaling units: The astrocyte-neuron "metabolic orchestra"

Sweet taste receptors can cooperatively bind mul- tiple molecules, mediating signals by other receptors (Welcome, 2015; Sivakumar and Bharathy, 2012) as these taste receptors are pleiotropic. This property is due to their multi-substrate affinity and summarized in Figure 4 Consequently, they are involved in the control of peripheral and central metabolism as well as other cellular activities. Several lines of evidence have suggested multiple interactions between membrane receptors resulting in either negative or positive cooperativity (Welcome, 2015; Urizar, 2005). The wide range of cellular signaling activities mediated by sweet taste receptors indicates possible cooperation with other membrane receptors, including the plasma membrane glucosensors. Research has shown that such interactions occur between several plasma membrane receptors and membrane glucosensors, including GLUT2 and SGLT3 (Welcome, 2015).

The incretin effect, secretion of hormones, and neurotransmitters occur due to activation of the corresponding membrane receptor signaling pathways of the hormone or neurotransmitter by downstream sweet taste receptor signaling that subsequently culminate in the mobilization of secretory vesicles to the plasma membrane for exocytosis (Kyriazis, 2012). This process occurs via cross-talk (Welcome, 2015) between sweet taste receptors and other glucosensors, as well as plasma membrane receptors associated with the astrocyte-neuron metabolic machinery (Figure 4). Receptor oligomerization and heterodimerization, as well as mosaic formation, are possible ways by which sweet taste receptors can cooperatively interact with a range of plasma membrane receptors to mediate physiological processes (Kuhn, 2010; Lee, 2015). For instance, functioning as immune custocytes, sweet taste receptor-expressing cells have also been shown to cooperate with bitter taste receptors (Lee, 2015). 


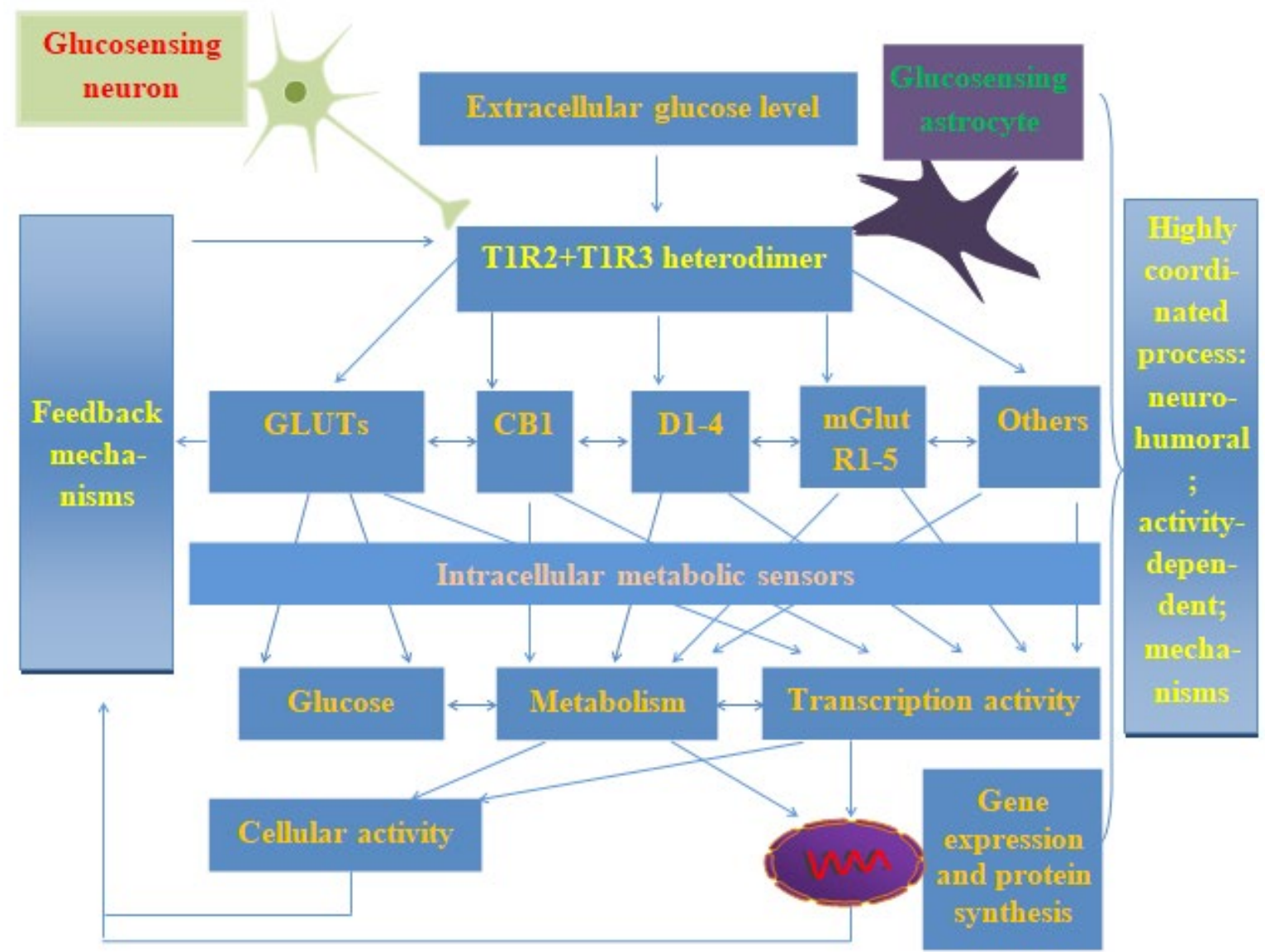

Figure 4. The metabolic orchestra of the heterodimer conductor, T1R2+T1R3, in the astrocyte-neuron circuitry. The taste receptor heterodimer senses extracellular glucose level. It mediates interactions with neighboring plasma receptors, including GLUTs (glucose transporters), CB1 (cannabinoid type 1) receptor, D1-4 (dopamine types 1-4) receptors, mGlutR1-5 (metabotropic glutamate) receptor types 1-5, GPR81 (lactate receptor) and SGLT3 (sodium glucose-dependent transporter type 3). Although the taste receptor heterodimer can signal downstream to affect gene expression and other cellular processes, their interactions with other membrane receptors can mediate a range of processes, including glucose metabolism, gene expression, and other cellular functions. Indeed, these receptors GLUTs (Welcome, 2015; Urizar, 2005), CB1 receptors, dopamine receptor, mGlutRs (Kuhn, 2010; Lee \& Cohen, 2015) have been implicated in metabolic dysfunctions. Further explanation is provided in the text.

\section{CONCLUSION}

The T1R2+T1R3 heterodimer is the director of glucose transport and metabolism not only in the periphery but also in the brain. This functional sweet taste receptor coordinates glucose transport and metabolism in both neurons and astrocytes. The pleiotropic signaling and multi-directional cross-talk with membrane glucosensors controlled by this receptor form a complex and highly coordinated network termed "metabolic orchestra" of the astrocyte-neuron circuitry, which is critical for both metabolic and cognitive processes in health and disease.

\section{CONFLICT OF INTEREST}

All the authors of this article declared no conflict of interest.

\section{AUTHOR CONTRIBUTION STATEMENT}

M.O.W. developed the hypothesis, conducted the literature search, analyzed the relevant literatures, prepared, edited, and revised the text. 


\section{REFERENCES}

Abdelaa, M., le Roux, C. W., Docherty, N. G. (2017). Morbidity and mortality associated with obesity. Annals of Translational Medicine, 5, 161. https:// doi.org/10.21037/atm.2017.03.107

Arroyo-Johnson, C., \& Mincey, K. D. (2016). Obesity epidemiology worldwide. Gastroenterology Clinics of North America, 45, 571-9. https://doi:10.1016/j. gtc.2016.07.012.

Attwell, D., \& Laughlin, S. B. (2001). An energy budget for signaling in the grey matter of the brain. Journal of Cerebral Blood Flow \& Metabolism, 21, 1133-45. https://doi/10.1097/00004647200110000-00001

Bady, I., Marty, N., Dallaporta, M., Emery, M., Gyger, J., Tarussio, D., Foretz, M., Thorens, B. (2006). Evidence from glut2-null mice that glucose is a critical physiological regulator of feeding. Diabetes, 55, 988-995. https://doi.org/10.2337/diabetes.55.04.06.db05-1386

Bak, L. K., Schousboe, A., \& Waagepetersen, H. S. (2011). Glutamate and glutamine in brain disorders. In: J. Blass (Ed.), Neurochemical mechanisms in disease. Advances in neurobiology (pp. 195-212). New York, United States of America: Springer.

Bartlett, E. J., Brown, J. W., Wolf, A. P., Brodie, J. D. (1987). Correlations between glucose metabolic rates in brain regions of healthy male adults at rest and during language stimulation. Brain and Language, 32,1-18. https://doi.org/10.1016/0093934X(87)90115-5

Behrens, P. F., Franz, P., Woodman, B., Lindenberg, K. S., Landwehrmeyer, G. B. (2002). Impaired glutamate transport and glutamate-glutamine cycling: downstream effects of the Huntington mutation. Brain, 125, 1908-1922. https://doi.org/10.1093/ brain/awf180

Belgardt, B. F., Okamura, T., Brüning, J. C. (2009). Hormone and glucose signalling in POMC and AgRP neurons. Journal of Physiology, 587, 5305-5314. https://doi.org/10.1113/jphysiol.2009.179192
Benford, H., Bolborea, M., Pollatzek, E., Lossow, K., Hermans-Borgmeyer, I., Liu, B., Meyerhof, W., Kasparov, S., Dale, N. (2017). A sweet taste receptor-dependent mechanism of glucosensing in hypothalamic tanycytes. Glia, 65, 773-789. https:// doi.org/10.1002/glia.23125

Bhutia, Y. D., \& Ganapathy, V. (2016). Glutamine transporters in mammalian cells and their functions in physiology and cancer. Biochimica et Biophysica Acta Molecular Cell Research, 1863, 2531-2539. https://doi.org/10.1016/j.bbamcr.2015.12.017

Blum-Degen, D., Frölich, L., Hoyer, S., Riederer, P. (1995). Altered regulation of brain glucose metabolism as a cause of neurodegenerative disorders? Journal of Neural Transmission, 46, 139-147.

Burdakov, D., Luckman, S. M., Verkhratsky, A. (2005). Glucose-sensing neurons of the hypothalamus. Philosophical Transactions of the Royal Society B: Biological Sciences, 360(1464), 2227-2235. https:// doi.org/10.1098/rstb.2005.1763

Cai, H., Cong, W., Ji, S., Rothman, S., Maudsley, S., Martin, B. (2012). Metabolic dysfunction in Alzheimer's disease and related neurodegenerative disorders. Current Alzheimer Research, 9(1): 5-17. https://doi.org/10.2174/156720512799015064

Chan, C. B., Hashemi, Z., \& Subhan, F. B. (2017). The impact of low and no-caloric sweeteners on glucose absorption, incretin secretion, and glucose tolerance. Applied Physiology, Nutrition and $\mathrm{Me}$ tabolism, 42(8), 793-801. https://doi.org/10.1139/ apnm-2016-0705

Chiba, Y., Sugiyama, Y., Nishi, N., Nonaka, W., Murakami, R., Ueno, M. (2020). Sodium/glucose cotransporter 2 is expressed in choroid plexus epithelial cells and ependymal cells in human and mouse brains. Neuropathology, 40(5), 482-491. https://doi.org/10.1111/neup.12665

Chin, J. H., \& Vora, N. (2014). The global burden of neurologic diseases. Neurology, 83(4), 349-351. https://doi.org/10.1212/WNL.0000000000000610 
De la Monte, S. M., Tong, M., Wands, J. R. (2018). The 20-year voyage aboard the Journal of Alzheimer's disease: docking at 'type 3 diabetes', environmental/exposure factors, pathogenic mechanisms, and potential treatments. Journal of Alzheimer's Disease, 62(3), 1381-1390. https://doi.org/10.3233/ JAD-170829

De Morentin, B. M. P., González, C. R., Saha, A. K., Martins, L., Diéguez, C., Vidal-Puig, A., Tena-Sempere, M., López, M. (2011). Hypothalamic AMP-activated protein kinase as a mediator of whole body energy balance. Reviews in Endocrine and Metabolic Disorders, 12(3), 127-140. doi: 10.1007/s11154-011-9165-5.

Depoortere, I. (2014). Taste receptors of the gut: emerging roles in health and disease. Gut, 63(1), 179-190. https://doi.org/10.1136/gutjnl-2013-305112

Díaz-García, C. M., \& Yellen, G. (2019). Neurons rely on glucose rather than astrocytic lactate during stimulation. Journal of Neuroscience Research, 97(8), 883-889. https://doi: 10.1002/jnr.24374

Dienel, G. A., \& Cruz, N. F. (2004). Nutrition during brain activation: does cell-to-cell lactate shuttling contribute significantly to sweet and sour food for thought? Neurochemistry International, 45(2-3), 321-351. https://doi.org/10.1016/j.neuint.2003.10.011

Dienel, G. A. (2017a). Lack of appropriate stoichiometry: Strong evidence against an energetically important astrocyte-neuron lactate shuttle in brain. Journal of Neuroscience Research, 95(11), 21032125. https://doi.org/10.1002/jnr.24015

Dienel, G. A. (2017b). The metabolic trinity, glucose-glycogen-lactate, links astrocytes and neurons in brain energetics, signaling, memory, and gene expression. Neuroscience Letters, 637, 18-25. https://doi.org/10.1016/j.neulet.2015.02.052

DiNuzzo, M., Mangia, S., Maraviglia, B., Giove, F. (2010). Changes in glucose uptake rather than lactate shuttle take center stage in subserving neuroenergetics: evidence from mathematical modeling. Journal of Cerebral Blood Flow \& Metabolism, 30(3),586-602. https://doi: 10.1038/jcbfm. 2009.232
Dobson, M. C., \& Gaunt, H. F. (2013). Musical and social communication in expert orchestral performance. Psychology of Music, 43, 24-42. https://doi: $10.1177 / 0305735613491998$

Duarte, A. C., Santos, J., Costa, A. R., Ferreira, C. L., Tomás, J., Quintela, T., Ishikawa, H., Schwerk, C., Schroten, H., Ferrer, I., Carro, E., Gonçalves, I., Santos, C. R. A. (2020). Bitter taste receptors profiling in the human blood-cerebrospinal fluid-barrier. Biochemical Pharmacology, 177, 113954. https://doi: 10.1016/j.bcp.2020.113954

Dunn, L., Allen, G. F. G., Mamais, A., Ling, H., Li, A., Duberley, K. E., Hargreaves, I. P., Pope, S., Holton, J.L., Lees, A., Heales, S.J., Bandopadhyay, R. (2014). Dysregulation of glucose metabolism is an early event in sporadic Parkinson's disease. Neurobiology of Aging, 35(5), 1111-1115. https:// doi.org/10.1016/j.neurobiolaging.2013.11.001

Duran, J., Tevy, M. F., Garcia-Rocha, M., Calbó, J., Milán, M., Guinovart, J. J. (2012). Deleterious effects of neuronal accumulation of glycogen in flies and mice. EMBO Molecular Medicine, 4(8), 719729. https://doi.org/10.1002/emmm.201200241

Essner, R. A., Smith, A. G., Jamnik, A. A., Ryba, A. R., Trutner, Z. D., Carter, M. E. (2017). AgRP neurons can increase food intake during conditions of appetite suppression and inhibit anorexigenic parabrachial neurons. Journal of Neuroscience, 37(36), 8678-8687. https://doi.org/10.1523/JNEUROSCI.0798-17.2017

Fioramonti, X., Contié, S., Song, Z., Routh, V. H., Lorsignol, A., Pénicaud, L. (2007). Characterization of glucosensing neuron subpopulations in the arcuate nucleus. Integration in neuropeptide $\mathrm{Y}$ and pro-opio melanocortin networks? Diabetes, 56(5), 1219-1227. https://doi.org/10.2337/db06-0567

Foo, K., Blumenthal, L., \& Man, H. Y. (2012). Regulation of neuronal bioenergy homeostasis by glutamate. Neurochemistry International, 61(3), 389396. https://doi.org/10.1016/j.neuint.2012.06.003

Ford, L., \& Davidson, J. W. (2003). An investigation of members' roles in wind quintets. Psychology of Music, 31(1), 53-74. https://doi.org/10.1177/0305 735603031001323

Forouhi, N. G., \& Wareham, N. J. (2014). Epidemiology of diabetes. Medicine, 42(12), 698-702. https:// doi.org/10.1016/j.mpmed.2014.09.007 
García, M., Millán, C., Balmaceda-Aguilera, C., Castro, T., Pastor, P., Montecinos, H., Reinicke, K., Zúñiga, F., Vera, J. C., Oñate, S. A., Nualart, F. (2003). Hypothalamic ependymal-glial cells express the glucose transporter GLUT2, a protein involved in glucose sensing. Journal of Neurochemistry, 86(3), 709-724. https://doi.org/10.1046/ j.1471-4159.2003.01892.x

Genc, S., Kurnaz, I. A., \& Ozilgen, M. (2011). Astrocyte-neuron lactate shuttle may boost more ATP supply to the neuron under hypoxic conditionsin silico study supported by in vitro expression data. BMC Systems Biology, 5, 162. https://doi. org/10.1186/1752-0509-5-162

Glendinning, J. I., Stano, S., Holter, M., Azenkot, T., Goldman, O., Margolskee, R. F., Vasselli, J. R., Sclafani, A. (2015). Sugar-induced cephalic-phase insulin release is mediated by a T1r2+T1r3-independent taste transduction pathway in mice. American Journal of Physiology - Regulatory, Integrative and Comparative Physiology, 309(5), R55260. https://doi.org/10.1152/ajpregu.00056.2015

Goldberger, A. L., Rigney, D. R., West, B. J. (1990). Chaos and fractals in human physiology. Scientific American, 262(2), 42-49.

Guo, C., Sun, L., Chen, X., Zhang, D. (2013). Oxidative stress, mitochondrial damage and neurodegenerative diseases. Neural Regeneration Research, 8(21), 2003-2014. https://doi.org/10.1155/2020/1270256

Gustavsson, A., Svensson, M., Jacobi, F., Allgulander, C., Alonso, J., Beghi, E., Dodel, R., Ekman, M., Faravelli, C., Fratiglioni, L., Gannon, B., Jones, D. H., Jennum, P., Jordanova, A., Jönsson, L., Karampampa, K., Knapp, M., Kobelt, G., Kurth, T., Lieb, R., ... CDBE2010Study Group (2011). Cost of disorders of the brain in Europe 2010. European Neuropsychopharmacology, 21(10), 718-779. https:// doi.org/10.1016/j.euroneuro.2011.08.008

Hall, C. N., Klein-Flügge, M. C., Howarth, C., Attwell, D. (2012). Oxidative phosphorylation, not glycolysis, powers presynaptic and postsynaptic mechanisms underlying brain information processing. Journal of Neuroscience, 32(26), 8940-8951. https://doi.org/10.1523/JNEUROSCI.0026-12.2012
Hamano, K., Nakagawa, Y., Ohtsu, Y., Li, L., Medina, J., Tanaka, Y., Masuda, K., Komatsu, M., Kojima, I. (2015). Lactisole inhibits the glucose-sensing receptor T1R3 expressed in mouse pancreatic $\beta$-cells. Journal of Endocrinology, 226(1), 57-66. https://doi.org/10.1530/JOE-15-0102

Hertz, L., Gibbs, M. E., Dienel, G. A. (2014). Fluxes of lactate into, from, and among gap junction-coupled astrocytes and their interaction with noradrenaline. Frontiers in Neuroscience, 8, 261. https://doi:10.3389/fnins.2014.00261

Hubbard, J. A., \& Binder, D. K. (2016). Glutamate metabolism. In: J. Hubbard, \& D. K. Binder (Eds.), Astrocytes and epilepsy (pp. 197-224). California, United States of America: Academic Press.

Jouroukhin, Y., Kageyama, Y., Misheneva, V., Shevelkin, A., Andrabi, S., Prandovszky, E., Yolken, R. H., Dawson, V. L., Dawson, T. M., Aja, S., Sesaki, H., Pletnikov, M. V. (2018). DISC1 regulates lactate metabolism in astrocytes: implications for psychiatric disorders. Translational Psychiatry, 8(1), 76. https://doi.org/10.1038/s41398-018-0123-9

Kaidanovich-Beilin, O., Cha, D. S., McIntyre, R. S. (2012). Crosstalk between metabolic and neuropsychiatric disorders. F1000 Biology Reports, 4, 14. https://doi.org/10.3410/B4-14

Kamat, P. K., Kalani, A., Rai, S., Tota, S. K., Kumar, A., Ahmad, A. S. (2016). Streptozotocin intracerebroventricular-induced neurotoxicity and brain insulin resistance: a therapeutic intervention for treatment of sporadic Alzheimer's disease (sAD)like pathology. Molecular Neurobiology, 53(7), 4548-4562. https://doi.org/10.1007/s12035-0159384-y

Kang, L., Routh, V. H., Kuzhikandathil, E. V., Gaspers, L. D., Levin, B. E. (2004). Physiological and molecular characteristics of rat hypothalamic ventromedial nucleus glucosensing neurons. Diabetes, 53(3), 549-559. https://doi.org/10.2337/diabetes.53.3.549

Kasischke, K. A. (2009). Activity-dependent metabolism in glia and neurons. In: L. R. Squire (Ed.), Encyclopedia of neuroscience (pp. 53-60). California, United States of America: Academic Press. 
Khatri, N., \& Man, H. Y. (2013). Synaptic activity and bioenergy homeostasis: implications in brain trauma and neurodegenerative diseases. Frontiers in Neurology, 4, 199. https://doi.org/10.3389/ fneur.2013.00199

Kochem M. (2017). Type 1 Taste Receptors in Taste and Metabolism. Annals of Nutrition \& Metabolism, 70, 27-36. https://doi.org/10.1159/000478760

Koekkoek, L. L., Mul, J. D., la Fleur, S. E. (2017). Glucose-Sensing in the Reward System. Frontiers in Neuroscience, 11, 716. https://doi.org/10.3389/ fnins.2017.00716

Kohno, D., Koike, M., Ninomiya, Y., Kojima, I., Kitamura, T., Yada, T. (2016). Sweet taste receptor serves to activate glucose- and leptin-responsive neurons in the hypothalamic arcuate nucleus and participates in glucose responsiveness. Frontiers in Neuroscience, 10, 502. https://doi:10.3389/ fnins.2016.00502

Kohno, D. (2017). Sweet taste receptor in the hypothalamus: a potential new player in glucose sensing in the hypothalamus. Journal of Physiological Sciences, 67(4), 459-465. https://doi.org/10.1007/ s12576-017-0535-y

Kong, L., Zhao, Y., Zhou, W. J., Yu, H., Teng, S. W., Guo, Q., Chen, Z., Wang, Y. (2017). Direct Neuronal Glucose Uptake Is Required for Contextual Fear Acquisition in the Dorsal Hippocampus. Frontiers in Molecular Neuroscience, 10, 388. https://doi.org/10.3389/fnmol.2017.00388

Kow, L. M., \& Pfaff, D. W. (1985). Actions of feeding-relevant agents on hypothalamic glucose-responsive neurons in vitro. Brain Research Bulletin, 15(5), 509-513. https://doi.org/10.1016/03619230(85)90041-3

Kuhn, C., Bufe, B., Batram, C., Meyerhof, W. (2010). Oligomerization of TAS2R bitter taste receptors. Chemical Senses, 35(5), 395-406. https://doi. org/10.1093/chemse/bjq027

Kyriazis, G. A., Soundarapandian, M. M., Tyrberg, B. (2012). Sweet taste receptor signaling in beta cells mediates fructose-induced potentiation of glucose-stimulated insulin secretion. Proceedings of the National Academy of Sciences of the United States of America, 109(8), E524-E532. https://doi. org/10.1073/pnas.1115183109
Lee, R. J., \& Cohen, N. A. (2015). Taste receptors in innate immunity. Cellular and Molecular Life Sciences : CMLS, 72(2), 217-236. https://doi. org/10.1007/s00018-014-1736-7

Lev-Vachnish, Y., Cadury, S., Rotter-Maskowitz, A., Feldman, N., Roichman, A., Illouz, T., Varvak, A., Nicola, R., Madar, R., Okun, E. (2019). L-Lactate Promotes Adult Hippocampal Neurogenesis. Frontiers in Neuroscience, 13, 403. https://doi. org/10.3389/fnins.2019.00403

Lim, M. C. (2014). In pursuit of harmony: the social and organisational factors in a professional vocal ensemble. Psychology of Music, 42(3),307-324. https://doi.org/10.1177/0305735612469674

Lozano, R., Naghavi, M., Foreman, K., Lim, S., Shibuya, K., Aboyans, V., Abraham, J., Adair, T., Aggarwal, R., Ahn, S. Y., Alvarado, M., Anderson, H. R., Anderson, L. M., Andrews, K. G., Atkinson, C., Baddour, L. M., Barker-Collo, S., Bartels, D. H., Bell, M. L., Benjamin, E. J., ... Memish, Z. A. (2012). Global and regional mortality from 235 causes of death for 20 age groups in 1990 and 2010: a systematic analysis for the Global Burden of Disease Study 2010. Lancet, 380(9859), 2095-2128. https://doi.org/10.1016/S0140-6736(12)61728-0

Lu, P., Zhang, C. H., Lifshitz, L. M., ZhuGe, R. (2017). Extraoral bitter taste receptors in health and disease. Journal of General Physiology, 149(2), 181197. https://doi.org/10.1085/jgp.201611637

Lundgaard, I., Li, B., Xie, L., Kang, H., Sanggaard, S., Haswell, J. D., Sun, W., Goldman, S., Blekot, S., Nielsen, M., Takano, T., Deane, R., Nedergaard, M. (2015). Direct neuronal glucose uptake heralds activity-dependent increases in cerebral metabolism. Nature Communications, 6, 6807. https://doi. org/10.1038/ncomms7807

Magistretti, P. J., \& Allaman, I. (2018). Lactate in the brain: from metabolic end-product to signalling molecule. Nature Reviews Neuroscience, 19(4), 235-249. https://doi.org/10.1038/nrn.2018.19

Mangia, S., Simpson, I. A., Vannucci, S. J., Carruthers, A. (2009). The in vivo neuron-to-astrocyte lactate shuttle in human brain: evidence from modeling of measured lactate levels during visual stimulation. Journal of Neurochemistry, 109 (Suppl 1), 55-62. https://doi.org/10.1111/j.1471-4159.2009.06003.x 
Margolskee R. F. (2002). Molecular mechanisms of bitter and sweet taste transduction. The Journal of Biological Chemistry, 277(1), 1-4. https://doi. org/10.1074/jbc.R100054200

Martin, B., Wang, R., Cong, W. N., Daimon, C. M., Wu, W. W., Ni, B., Becker, K. G., Lehrmann, E., Wood, W. H., 3rd, Zhang, Y., Etienne, H., van Gastel, J., Azmi, A., Janssens, J., Maudsley, S. (2017). Altered learning, memory, and social behavior in type 1 taste receptor subunit 3 knock-out mice are associated with neuronal dysfunction. Journal of Biological Chemistry, 292(27), 11508-11530. https://doi.org/10.1074/jbc.M116.773820

Marty, N., Dallaporta, M., Thorens, B. (2007). Brain glucose sensing, counterregulation, and energy homeostasis. Physiology (Bethesda, Md.), 22, 241251. https://doi.org/10.1152/physiol.00010.2007

Meyerhof, W., Batram, C., Kuhn, C., Brockhoff, A., Chudoba, E., Bufe, B., Appendino, G., Behrens, M. (2010). The molecular receptive ranges of human TAS2R bitter taste receptors. Chemical Senses, 35(2), 157-170. https://doi.org/10.1093/chemse/ bjp092

Mizuno, Y., \& Oomura, Y. (1984). Glucose responding neurons in the nucleus tractus solitarius of the rat: in vitro study. Brain Research, 307(1-2), 109-116. https://doi.org/10.1016/0006-8993(84)90466-9

Murovets, V. O., Bachmanov, A. A., Travnikov, S. V., Tchurikova, A. A., Zolotarev, V. A. (2014). The involvement of the T1R3 receptor protein in the control of glucose metabolism in mice at different levels of glycemia. Journal of Evolutionary Biochemistry and Physiology, 50, 334-344. https://doi. org/10.1134/S0022093014040061

Murovets, V. O., Bachmanov, A. A., Zolotarev, V. A. (2015). Impaired Glucose Metabolism in Mice Lacking the Tas1r3 Taste Receptor Gene. PloS One, 10(6), e0130997. https://doi.org/10.1371/ journal.pone. 0130997

Newman, L. A., Korol, D. L., Gold, P. E. (2011). Lactate produced by glycogenolysis in astrocytes regulates memory processing. PloS One, 6(12), e28427. https://doi.org/10.1371/journal.pone.0028427

Patel, A. B., Lai, J. C., Chowdhury, G. M., Hyder, F., Rothman, D. L., Shulman, R. G., Behar, K. L.
(2014). Direct evidence for activity-dependent glucose phosphorylation in neurons with implications for the astrocyte-to-neuron lactate shuttle. Proceedings of the National Academy of Sciences of the United States of America, 111(14), 5385-5390. https://doi.org/10.1073/pnas.1403576111

Pellerin, L., Bouzier-Sore, A. K., Aubert, A., Serres, S., Merle, M., Costalat, R., Magistretti, P. J. (2007). Activity-dependent regulation of energy metabolism by astrocytes: an update. Glia, 55(12), 12511262. https://doi.org/10.1002/glia.20528

Pellerin, L., \& Magistretti, P. J. (1994). Glutamate uptake into astrocytes stimulates aerobic glycolysis: a mechanism coupling neuronal activity to glucose utilization. Proceedings of the National Academy of Sciences of the United States of America, 91(22), 10625-10629. https://doi.org/10.1073/ pnas.91.22.10625

Peters, A., Schweiger, U., Pellerin, L., Hubold, C., Oltmanns, K. M., Conrad, M., Schultes, B., Born, J., Fehm, H. L. (2004). The selfish brain: competition for energy resources. Neuroscience and Biobehavioral Reviews, 28(2), 143-180. https://doi. org/10.1016/j.neubiorev.2004.03.002

Petroff, O. A. C. (2007). Metabolic biopsy of the brain. In: S. G, Waxman (Ed.), Molecular neurology (pp. 77-100). California, , United States of America: Academic Press.

Pfeiffer-Guglielmi, B., Dombert, B., Jablonka, S., Hausherr, V., van Thriel, C., Schöbel, N., Jansen, R. P. (2014). Axonal and dendritic localization of mRNAs for glycogen-metabolizing enzymes in cultured rodent neurons. BMC Neuroscience, 15, 70. https://doi.org/10.1186/1471-2202-15-70

Porras, O. H., Loaiza, A., Barros, L. F. (2004). Glutamate mediates acute glucose transport inhibition in hippocampal neurons. Journal of Neuroscience, 24(43), 9669-73. https://doi: 10.1523/JNEUROSCI.1882-04.2004

Procaccini, C., Santopaolo, M., Faicchia, D., Colamatteo, A., Formisano, L., de Candia, P., Galgani, M., De Rosa, V., Matarese, G. (2016). Role of metabolism in neurodegenerative disorders. Metabolism: Clinical and Experimental, 65(9), 1376-1390. https://doi.org/10.1016/j.metabol.2016.05.018 
Rao, J., Oz, G., \& Seaquist, E. R. (2006). Regulation of cerebral glucose metabolism. Minerva Endocrinologica, 31(2), 149-158.

Ren, X., Zhou, L., Terwilliger, R., Newton, S. S., de Araujo, I. E. (2009). Sweet taste signaling functions as a hypothalamic glucose sensor. Frontiers in Integrative Neuroscience, 3, 12. https://doi. org/10.3389/neuro.07.012.2009

Roh, E., Song, D. K., Kim, M. S. (2016). Emerging role of the brain in the homeostatic regulation of energy and glucose metabolism. Experimental \& Molecular Medicine, 48(3), e216. https://doi. org/10.1038/emm.2016.4

Rubio-Aliaga, I., Wagner, C. A. (2016). Regulation and function of the SLC38A3/SNAT3 glutamine transporter. Channels, 10(6), 440-452. https://doi. org/10.1080/19336950.2016.1207024

Saez, I., Duran, J., Sinadinos, C., Beltran, A., Yanes, O., Tevy, M. F., Martínez-Pons, C., Milán, M., Guinovart, J. J. (2014). Neurons have an active glycogen metabolism that contributes to tolerance to hypoxia. Journal of Cerebral Blood Flow and Metabolism, 34(6), 945-955. https://doi.org/10.1038/ jcbfm.2014.33

Shah, K., Desilva, S., Abbruscato, T. (2012). The role of glucose transporters in brain disease: diabetes and Alzheimer's Disease. International Journal of Molecular Sciences, 13(10), 12629-12655. https:// doi.org/10.3390/ijms131012629

Sivakumar, S., Bharathy, G. (2012). Molecular mechanism of interaction between human sweet taste receptors andantidiabetic agents of Gymnema sylvestre through docking studies. International Journal of Research in Phytochemistry \& Pharmacology, 2(4), 164-170. https://scienztech.org/ijrpp/ article/view/828

Supplie, L. M., Düking, T., Campbell, G., Diaz, F., Moraes, C. T., Götz, M., Hamprecht, B., Boretius, S., Mahad, D., Nave, K. A. (2017). Respiration-Deficient Astrocytes Survive As Glycolytic Cells In Vivo. Journal of Neuroscience, 37(16), 4231-4242. https://doi.org/10.1523/JNEUROSCI.0756-16.2017
Suzuki, A., Stern, S. A., Bozdagi, O., Huntley, G. W., Walker, R. H., Magistretti, P. J., Alberini, C. M. (2011). Astrocyte-neuron lactate transport is required for long-term memory formation. Cell, 144(5), 810-823. https://doi.org/10.1016/j. cell.2011.02.018

Urizar, E., Montanelli, L., Loy, T., Bonomi, M., Swillens, S., Gales, C., Bouvier, M., Smits, G., Vassart, G., Costagliola, S. (2005). Glycoprotein hormone receptors: link between receptor homodimerization and negative cooperativity. EMBO Journal, 24(11), 1954-1964. https://doi.org/10.1038/sj.emboj.7600686

van Dieren, S., Beulens, J. W., van der Schouw, Y. T., Grobbee, D. E., Neal, B. (2010). The global burden of diabetes and its complications: an emerging pandemic. European Journal of Cardiovascular Prevention and Rehabilitation, 17 Suppl 1, S3-S8. https:// doi.org/10.1097/01.hjr.0000368191.86614.5a

Veldhuizen, M. G., Babbs, R. K., Patel, B., Fobbs, W., Kroemer, N. B., Garcia, E., Yeomans, M. R., Small, D. M. (2017). Integration of Sweet Taste and Metabolism Determines Carbohydrate Reward. Current Biology, 27(16), 2476-2485.e6. https://doi. org/10.1016/j.cub.2017.07.018

Vercruysse, P., Vieau, D., Blum, D., Petersén, Å., Dupuis, L. (2018). Hypothalamic Alterations in Neurodegenerative Diseases and Their Relation to Abnormal Energy Metabolism. Frontiers in Molecular Neuroscience, 11, 2. https://doi.org/10.3389/ fnmol.2018.00002

Welcome, M. O., Mastorakis, N. E., Pereverzev, V. A. (2015). Sweet taste receptor signaling network: possible implication for cognitive functioning. Neurology Research International, 2015, 606479. https://doi.org/10.1155/2015/606479

Welcome, M., \& Pereverzev, V. (2014). Glycemic allostasis during mental activities on fasting in non-alcohol users and alcohol users with different durations of abstinence. Annals of Medical and Health Sciences Research, 4(Suppl 3), S199-S207. https://doi.org/10.4103/2141-9248.141959 
Welcome, M. O. (2018). Gastrointestinal physiology: development, principles and mechanism of regulation. Cham, Switzerland: Springer International Publishing AG. https://doi: 10.1007/978-3-31991056-7.

Westrup, J. (2001). Instrumentation and orchestration: 3.1750 to 1800. In: S. Sadie (Ed.), New grove dictionary of music and musicians. New York, United States of America: NUSA.

Wiesinger, H., Hamprecht, B., Dringen, R. (1997). Metabolic pathways for glucose in astrocytes. Glia, 21(1), 22-34. https://doi.org/10.1002/(sici)10981136(199709)21:1<22::aid-glia3>3.0.co;2-3

Wittchen, H. U., Jacobi, F., Rehm, J., Gustavsson, A., Svensson, M., Jönsson, B., Olesen, J., Allgulander, C., Alonso, J., Faravelli, C., Fratiglioni, L., Jennum, P., Lieb, R., Maercker, A., van Os, J., Preisig, M., Salvador-Carulla, L., Simon, R., Steinhausen, H.
C. (2011). The size and burden of mental disorders and other disorders of the brain in Europe 2010. European Neuropsychopharmacology, 21(9), 655-679. https://doi.org/10.1016/j.euroneuro.2011.07.018

Yee, K. K., Sukumaran, S. K., Kotha, R., Gilbertson, T. A., Margolskee, R. F. (2011). Glucose transporters and ATP-gated $\mathrm{K}+$ (KATP) metabolic sensors are present in type 1 taste receptor 3 (T1r3)-expressing taste cells. Proceedings of the National Academy of Sciences of the United States of America, 108(13), 5431-5436. https://doi.org/10.1073/ pnas. 1100495108

Zhou, L., Huang, W., Xu, Y., Gao, C., Zhang, T., Guo, M., Liu, Y., Ding, J., Qin, L., Xu, Z., Long, Y., Xu, Y. (2018). Sweet taste receptors mediated ROS-NLRP3 inflammasome signaling activation: implications for diabetic nephropathy. Journal of Diabetes Research, 2018, 7078214. https://doi. org/10.1155/2018/7078214 